\title{
Perbandingan Akurasi Peramalan Curah Hujan dengan menggunakan ARIMA, Hybrid ARIMA-NN, dan FFNN di Kabupaten Malang
}

\author{
(Comparison of Rainfall Forecasting Accuracy using ARIMA, Hybrid ARIMA-NN, and FFNN \\ in Malang District)
}

\author{
Bestari Archita Safitri ${ }^{1 *}$, Atiek Iriany ${ }^{2}$, dan Ni Wayan Surya Wardhani ${ }^{3}$ \\ ${ }_{1,2,3}$ Universitas Brawijaya \\ Email: ${ }^{1}$ bestariarchitasafitri@gmail.com, ${ }^{2}$ atiekiriany@ub.ac.id, ${ }^{3}$ wswardhani@ub.ac.id
}

\begin{abstract}
ABSTRAK
Analisis deret waktu adalah suatu pengamatan yang dibangun berdasarkan urutan waktu. Peranan analisis deret waktu bermanfaat di berbagai bidang khususnya meteorologi. Salah satu aspek meteorologi adalah curah hujan, yang mana dapat memberikan dampak bagi kehidupan manusia. Curah hujan memiliki pola yang rumit untuk diprediksi, sehingga diperlukan metode terbaik untuk meramalkan curah hujan. Terdapat beberapa metode yang mampu menganalisis intensitas curah hujan. Metode yang dapat digunakan untuk meramalkan curah hujan adalah metode ARIMA, metode Feed Forward Neural Network (FFNN), dan hybrid ARIMA-NN. Penelitian ini bertujuan untuk mendapatkan pemodelan dan prediksi curah hujan yang terbaik berdasarkan ketiga metode di atas. Data curah hujan yang digunakan berasal dari alat Mini Weather Station (MWS) di lokasi Dusun Supiturang dan Dusun Manggisari. Berdasarkan hasil penelitian, pada lokasi Supiturang didapatkan model terbaik yaitu ARIMA $(1,1,1)$ dengan RMSE sebesar 3,4326. Pada lokasi Manggisari didapatkan model terbaik yaitu Hybrid ARIMA(1,1,1) FFNN(4-9-1) dengan RMSE sebesar 3,1056.
\end{abstract}

Kata Kunci: ARIMA, Curah Hujan, FFNN, Hybrid ARIMA-NN, RMSE.

\begin{abstract}
Time series analysis is an observation that is built on time sequences. Time series analysis is useful in various fields, especially meteorology. One aspect of meteorology is rainfall, which can have an impact on human life. Rainfall has a complicated pattern to predict, so we need the best method for forecasting rainfall. There are several methods that can analyze the intensity of rainfall. Methods that can be used to predict rainfall are ARIMA method, Feed Forward Neural Network (FFNN) method, and hybrid ARIMA-NN. This study aims to obtain the best rainfall modeling and prediction based on the three methods above. The rainfall data used came from the Mini Weather Station (MWS) at Supiturang and Manggisari hamlets. Based on the results of the study, at Supiturang, the best model was ARIMA(1,1,1) with RMSE of 3.4326. At Manggisari, the best model is Hybrid ARIMA(1,1,1) FFNN(4-9-1) with RMSE of 3.1056.
\end{abstract}

Keywords: ARIMA, FFNN, Hybrid ARIMA-NN, Rainfall, RMSE.

\section{PENDAHULUAN}

Negara Indonesia adalah titik temu sirkulasi meridional (Utara-Selatan) atau Hardley dan sirkulasi zonal (Timur-Barat) atau Walker yang berpengaruh pada keragaman iklim di Indonesia (Saputro, 2009). Selain itu, peningkatan konsentrasi rumah kaca di atmosfer juga menyebabkan perubahan iklim yang tidak terkendali dan berpotensi mengubah pola cuaca secara ekstrem di berbagai negara termasuk Indonesia. Curah hujan di Indonesia memiliki pola yang rumit dan sulit diprediksi, sehingga memerlukan metode khusus dalam menangani kondisi tersebut. Data curah hujan memiliki keterkaitan dengan waktu, oleh karena itu digunakan analisis deret waktu dengan memanfaatkan data curah hujan pada waktu sebelumnya untuk meramalkan curah hujan pada waktu yang akan datang (Wei, 2006).

Terdapat beberapa metode yang dapat digunakan dalam peramalan curah hujan, yaitu metode Autoregressive Integrated Moving Average (ARIMA) yang dikembangkan oleh Box dan Jenkins (1976). Metode ARIMA menjelaskan keterkaitan antar pengamatan pada variabel di suatu waktu dengan pengamatan variabel pada waktu sebelumnya, metode ARIMA baik digunakan untuk analisis data berpola linier. Selain ARIMA, terdapat metode lain yaitu Neural Network (NN). NN memudahkan dalam analisis data berpola linier maupun nonlinier. Salah satu arsitektur jaringan NN adalah Feed Forward Neural Network (FFNN). Zhang (2003) memperkenalkan kombinasi model ARIMA dengan NN. Pengombinasian dua metode tersebut dapat menjadi alternatif dalam melakukan peramalan data deret waktu jarang yang memiliki pola linier ataupun nonlinier. 
Beberapa penelitian curah hujan yang sudah dilakukan diantaranya Susanto (2016) yaitu pemodelan curah hujan dengan pendekatan ARIMA, FFNN, dan Hybrid ARIMA-NN di Banyuwangi, didapatkan hasil penelitian bahwa model FFNN (3-3-1) merupakan pendekatan model terbaik dikarenakan memiliki nilai RMSE out sample terkecil apabila dibandingkan dengan ARIMA dan Hybrid (ARIMA-NN). Wahyuni dkk. (2017) meneliti tentang peramalan curah hujan menggunakan Hybrid Adaptive Neuro-Fuzzy Inference System (ANFIS) dan Algoritma Genetik, hasil penelitian menunjukkan bahwa ANFIS-GA menghasilkan RMSE terkecil dibanding metode lain. Penelitian Iriany dkk. (2020) tentang peramalan curah hujan menggunakan pendekatan model neural network, didapatkan hasil bahwa NN-GSTAR-SUR adalah model terbaik dan akurat untuk meramalkan curah hujan.

Pada pemodelan curah hujan ini, peneliti ingin melakukan penelitian dengan menggunakan pendekatan ARIMA, Hybrid ARIMA-NN, dan FFNN di Kabupaten Malang. Pemodelan dengan metode tersebut diharapkan dapat menghasilkan model yang terbaik dan prediksi yang akurat untuk data curah hujan tersebut.

\section{METODE}

Penelitian ini menggunakan pendekatan metode ARIMA dan FFNN serta kombinasi dari metode ARIMA dan FFNN atau Hybrid ARIMA-NN. Software yang digunakan adalah Excel, R, dan Minitab.

\section{Sumber Data}

Penelitian ini menggunakan data sekunder curah hujan di lokasi Supiturang dan Manggisari dari alat Mini Weather Station (MWS) oleh Iriany dkk. (2019) dengan data update per 5 menit setiap hari. Lokasi Supiturang dimulai pada periode tanggal 1 hingga 24 Februari 2021, sebanyak 4476 data. Sedangkan, lokasi Manggisari periode mulai tanggal 2 hingga 16 Desember 2020, sebanyak 3918 data.

\section{Metode Analisis Data}

\section{a. Pemodelan ARIMA}

1. Melakukan uji stasioneritas ragam menggunakan transformasi Box-Cox menggunakan rumus:

$T\left(Z_{t}\right)=\frac{Z_{t}^{\lambda}-1}{\lambda}($ Wei, 2006)

dimana:

$T\left(Z_{t}\right) \quad=$ transformasi Box-Cox

$Z_{t} \quad=$ pengamatan pada periode waktu ke- $t$

$\lambda \quad=$ parameter transformasi

2. Melakukan uji stasioneritas rata-rata menggunakan plot ACF atau menggunakan Uji Augmented Dickey Fuller (ADF).

$\Delta Z_{t}=\beta_{0}+\left(\beta_{1}-1\right) Z_{t-1}+a_{t}$

$\Delta Z_{t}=\beta_{0}+\gamma Z_{t-1}+a_{t}$

Dengan $\Delta Z_{t}=Z_{t}-Z_{t-1}$ dan $\gamma=\left(\beta_{1}-1\right)$. Jika $\gamma=0$, maka $\beta_{1}=1$ artinya $Z_{t}$ memiliki akar unit atau data tidak stasioner terhadap rata-rata. Parameter $\gamma$ diestimasi menggunakan metode Ordinary Least Square (OLS) dengan statistik uji $\tau$ dan membandingkan nilai uji terhadap tabel kritis Dickey Fuller $\tau=\frac{\widehat{\gamma}-\gamma}{s e(\widehat{\gamma})}$ (Rusdi, 2011)

dimana:

$Z_{t-1} \quad=$ pengamatan pada periode waktu ke- $(t-1)$

$\Delta Z_{t} \quad=$ hasil differencing pertama pengamatan $Z_{t}$

$\tau \quad=$ statistik uji

$\gamma \quad=$ parameter

$\operatorname{se}(\hat{\gamma})=$ standart error penduga parameter model

3. Menentukan orde ARIMA berdasarkan plot ACF dan PACF.

4. Menduga parameter model menggunakan Ordinary Least Square (OLS) menggunakan rumus:

$\widehat{\phi}=\frac{\sum_{t=2}^{n} Z_{t-1} Z_{t}}{\sum_{t=2}^{n} Z^{2} t-1}($ Wei, 2006)

dimana:

$\hat{\phi} \quad=$ penduga parameter OLS

5. Menguji signifikansi parameter dengan statistik uji $t$ menggunakan rumus:

$t=\frac{\widehat{\phi}_{i}}{\left.s e \widehat{\phi}_{i}\right)} \sim t_{(n-p)}($ Wei, 2006) 
dimana:

$\hat{\phi}_{i} \quad=$ penduga parameter model

$\operatorname{se}\left(\hat{\phi}_{i}\right)=$ standart error penduga parameter model

$p \quad=$ banyak parameter

$n \quad$ = banyak pengamatan

6. Melakukan pengujian asumsi white noise sisaan model dengan uji Ljung-Box menggunakan rumus:

$Q=n(n+2) \sum_{k=1}^{k} \frac{\widehat{\rho}^{2}{ }_{k}}{n-k} \sim \chi_{(k-m)}^{2}($ Wei, 2006)

dimana:

$k=$ banyak autokorelasi yang diuji

$n \quad=$ banyak pengamatan

$m \quad=$ banyak parameter yang diduga pada model $(m=p+q)$

$\hat{\rho}_{k} \quad=$ penduga autokorelasi sisaan pada lag ke- $k$

7. Melakukan pengujian normalitas sisaan model dengan uji statistik Kolmogorov-Smirnov menggunakan rumus:

$D=\operatorname{maks}\left|F_{n}(x)-F_{0}(x)\right| \sim D_{(N)}$

dimana:

$F_{n}(x) \quad=$ fungsi kumulatif data contoh

$F_{0}(x) \quad=$ fungsi kumulatif distribusi normal

8. Memilih model terbaik ARIMA berdasarkan kriteria Root Mean Square Error (RMSE) menggunakan rumus:

$R M S E=\sqrt{\frac{\sum_{t=1}^{n}\left(\hat{Z}_{t}-Z_{t}\right)^{2}}{n}}($ Willmott dan Matsuura, 2005)

dimana:

$Z_{t} \quad=$ pengamatan pada periode waktu ke- $t$

$n \quad=$ banyak pengamatan

\section{b. Pemodelan FFNN}

1. Menentukan input berdasarkan lag PACF yang signifikan pada data.

2. Melakukan normalisasi data input menggunakan persamaan:

$X^{\prime}=\frac{x-a}{b-a}$ (Patro dan Sahu, 2015).

dimana:

$a \quad$ = data minimum

$b \quad=$ data maksimum

$x \quad=$ data asli

$X^{\prime} \quad=$ data normalisasi

3. Menentukan banyaknya neuron dan hidden layer

4. Melakukan pembelajaran jaringan menggunakan Algoritma Backpropagation.

5. Melakukan denormalisasi data output menggunakan rumus:

$X=a+(\hat{y}(b-a))$

dimana:

$$
\begin{array}{ll}
a & =\text { data minimum } \\
b & =\text { data maksimum } \\
x & =\text { data asli } \\
\hat{y} & =\text { data keluaran (output) }
\end{array}
$$

6. Memilih model terbaik berdasarkan kriteria RMSE dari data training maupun testing.

c. Pemodelan Hybrid ARIMA-NN

1. Menentukan input berdasarkan plot PACF sisaan pemodelan ARIMA.

2. Melakukan normalisasi data input sisaan ARIMA

3. Menentukan banyaknya neuron dan hidden layer

4. Melakukan pembelajaran jaringan menggunakan Algoritma Backpropagation.

5. Melakukan denormalisasi data output

6. Memilih model terbaik berdasarkan kriteria RMSE data training maupun testing. 


\section{HASIL DAN PEMBAHASAN}

Data curah hujan pertama yang digunakan adalah data curah hujan di lokasi Supiturang. Gambaran awal mengenai curah hujan Supiturang dapat diketahui melalui plot curah hujan pada Gambar 1.

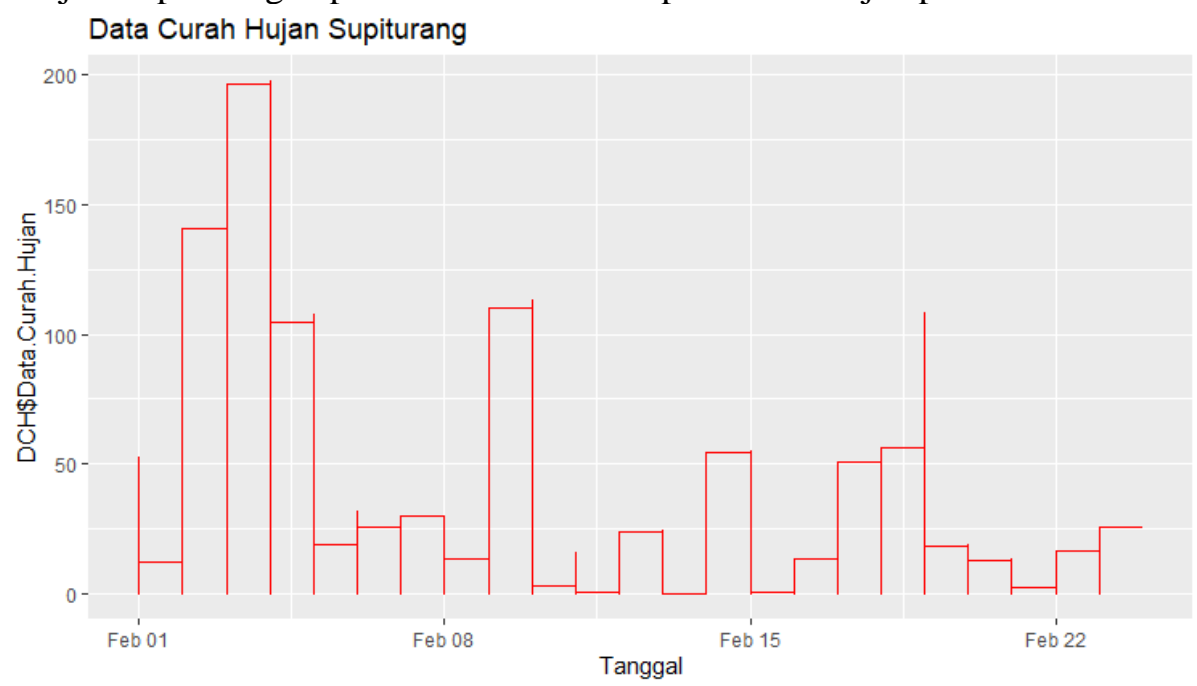

Gambar 1. Curah hujan daerah Supiturang.

Pada Gambar 1. diketahui awal bulan Februari curah hujan sangat tinggi, sedangkan pada akhir Februari curah hujan tergolong lebih rendah. Sebagian besar curah hujan yang terjadi di Supiturang sebesar 31,29 mm dengan curah hujan maksimal sebesar 197,54 mm.

Sebelum melakukan pemodelan pada data curah hujan menggunakan pendekatan ARIMA, Hybrid ARIMA-NN dan FFNN, dilakukan pengujian linieritas terhadap data yang akan digunakan. Pengujian tersebut dilakukan untuk mengetahui dan menangkap pola nonlinier pada data. Berdasarkan hasil pengujian linieritas diketahui bahwa $p$-value $(0,3707)>\alpha(0,05)$, maka dapat diputuskan menerima $\mathrm{H}_{0}$. Pada pengujian linieritas ini, dapat disimpulkan bahwa data curah hujan memiliki pola linier. Meskipun data yang digunakan dinyatakan linier, hal tersebut tidak menutup kemungkinan untuk tetap dilakukan pemodelan curah hujan menggunakan pendekatan Neural Network (NN) yang dapat mengatasi data yang berpola linier atau nonlinier.

Pemodelan curah hujan dengan ARIMA perlu dilakukan pengecekan stasioneritas terhadap ragam dan rata-rata. Data Supiturang tidak stasioner terhadap ragam karena memiliki $\lambda$ sebesar 0,24 yang belum mendekati 1, sehingga diperlukan transformasi Box-Cox agar stasioner. Stasioneritas terhadap rata-rata diketahui melalui pengujian Augmented Dickey Fuller (ADF) dengan $p$-value $(0,01)<\alpha(0,05)$, sehingga data stasioneritas terhadap rata-rata. Tahap selanjutnya adalah pendugaan dan pengujian signifikansi parameter model yang dapat diketahui melalui Tabel 1 .

Tabel 1. Pendugaan parameter dan uji signifikansi model Supiturang.

\begin{tabular}{cccccc}
\hline \multirow{2}{*}{ Model } & \multirow{2}{*}{$\begin{array}{c}\text { Penduga } \\
\text { Parameter }\end{array}$} & \multirow{2}{*}{ thitung } & \multicolumn{2}{c}{ t tabel } & \multirow{2}{*}{ Keterangan } \\
\cline { 4 - 5 } & & $t_{(0.05,3133-p)}$ & $t_{(0.1,3133-p)}$ & \\
\hline \multirow{2}{*}{ ARIMA $(1,1,1)$} & $\phi_{1}=0,7546$ & 2,8615 & 1.9607 & 1.6453 & Signifikan \\
ARIMA $(1,1,0)$ & $\theta_{1}=-0,7317$ & 2,6743 & 1.9607 & 1.6453 & Signifikan \\
ARIMA $(0,1,1)$ & $\phi_{1}=0,0280$ & 1,5642 & 1.9607 & 1.6453 & Tidak Signifikan \\
\hline
\end{tabular}

Pada Tabel 1, diketahui bahwa hanya model ARIMA $(1,1,1)$ yang memiliki parameter signifikan, dengan koefisien penduga $\phi_{1}=0,7546$ dan $\theta_{1}=-0,7317$. Pengujian asumsi white noise dan normalitas sisaan ARIMA $(1,1,1)$, diketahui bahwa asumsi white noise terpenuhi karena $p$-value $(0,9762)>\alpha(0,05)$. Namun, pada asumsi normalitas tidak terpenuhi karena $p$-value $\left(2,2 \times 10^{-16}\right)<\alpha(0,05)$, hal ini terjadi dimungkinkan terdapat pencilan pada data Supiturang. Pemilihan model terbaik ARIMA yaitu ARIMA $(1,1,1)$ memiliki RMSE data training sebesar 5,6056 dan data testing sebesar 3,4326. Persamaan model ARIMA $(1,1,1)$ dapat ditulis sebagai berikut:

$Z_{t}=(1+\phi) Z_{t-1}+\phi Z_{t-2}+a_{t}-\theta_{1} a_{t-1}$

$Z_{t}=1,7546 Z_{t-1}+0,7546 Z_{t-2}+a_{t}+0,7317 a_{t-1}$ 
Pemodelan curah hujan menggunakan Hybrid ARIMA-NN merupakan kombinasi pemodelan linier ARIMA dengan nonlinier Neural Network. Input yang digunakan merupakan sisaan model ARIMA. Tahap awal pemodelan Hybrid ARIMA-NN yaitu normalisasi data dengan interval $[0,1]$. Kemudian, membentuk arsitektur jaringan dengan jumlah hidden layer sebanyak 1 dan menguji coba (trial and error) 2-10 neuron pada hidden layer untuk mendapatkan error model terkecil. Arsitektur yang terbentuk dapat diketahui pada Tabel 2 berikut.

Tabel 2. Arsitektur jaringan hybrid ARIMA-NN Supiturang.

\begin{tabular}{ccccc}
\hline No. & Hidden Layer & Arsitektur Jaringan & RMSE training & RMSE testing \\
\hline 1 & 2 & Hybrid (ARIMA (1,1,1) FFNN (4-2-1)) & 10,2986 & 3,4327 \\
2 & 3 & Hybrid (ARIMA (1,1,1) FFNN (4-3-1)) & 10,2981 & 3,4330 \\
3 & 4 & Hybrid (ARIMA (1,1,1) FFNN (4-4-1)) & 10,2854 & 3,4338 \\
4 & 5 & Hybrid (ARIMA (1,1,1) FFNN (4-5-1)) & 10,3002 & 3,4350 \\
5 & 6 & Hybrid (ARIMA (1,1,1) FFNN (4-6-1)) & 10,2966 & 3,4326 \\
6 & 7 & Hybrid (ARIMA (1,1,1) FFNN (4-7-1)) & 10,3017 & 3,4322 \\
7 & 8 & Hybrid (ARIMA (1,1,1) FFNN (4-8-1)) & 10,2815 & 3,4334 \\
8 & 9 & Hybrid (ARIMA (1,1,1) FFNN (4-9-1)) & 10,2955 & 3,4336 \\
9 & 10 & Hybrid (ARIMA (1,1,1) FFNN (4-10-1)) & 10,3040 & 3,4323 \\
\hline
\end{tabular}

Berdasarkan Tabel 2, model ARIMA(1,1,1) FFNN(4-8-1) memiliki RMSE data training terkecil sebesar 10,2815 dan RMSE data testing sebesar 3,4334. Pembentukan arsitektur Hybrid ARIMA-NN ditentukan oleh bobot. Semakin besar bobot, semakin penting hubungan diantara neuron, hal tersebut dapat diketahui pada Tabel 3.

Tabel 3. Bobot akhir hidden layer ke output Supiturang.

\begin{tabular}{|c|c|}
\hline \multirow{2}{*}{$\mathrm{W}[\mathrm{i}]}$, & $\mathrm{W}[\mathrm{j}]$ \\
\hline & 1 \\
\hline 0 & $-0,0088$ \\
\hline 1 & $-1,2206$ \\
\hline 2 & 0,3435 \\
\hline 3 & 0,3054 \\
\hline 4 & 0,6341 \\
\hline 5 & 0,8521 \\
\hline 6 & 0,5193 \\
\hline 7 & $-1,1905$ \\
\hline 8 & 0,6199 \\
\hline
\end{tabular}

Berdasarkan Tabel 3, dapat diketahui bahwa output model Hybrid ARIMA $(1,1,1)$ FFNN (4-8-1) secara matematis:

$\widehat{N}_{t}=-0,0088-1,2206 f_{1}{ }^{h}+0,3435 f_{2}{ }^{h}+0,3054 f_{3}{ }^{h}+0,6341{f_{4}}^{h}+0,8521 f_{5}{ }^{h}+0,5193 f_{6}{ }^{h}-1,1905 f_{7}{ }^{h}+$ $0,6199 f_{8}{ }^{h}$

Model Hybrid ARIMA-NN terbaik adalah Hybrid ARIMA(1,1,1) FFNN (4-8-1) dengan persamaan sebagai berikut.

$\hat{Z}_{t}=\widehat{L}_{t}+\widehat{N}_{t}$

$\hat{Z}_{t}=1,7546 Z_{t-1}+0,7546 Z_{t-2}+a_{t}+0,7317 a_{t-1}-0,0088-1,2206 f_{1}{ }^{h}+0,3435 f_{2}{ }^{h}+0,3054 f_{3}{ }^{h}+0,6341$ $f_{4}{ }^{h}+0,8521 f_{5}{ }^{h}+0,5193 f_{6}{ }^{h}-1,1905 f_{7}{ }^{h}+0,6199 f_{8}{ }^{h}$

Pemodelan curah hujan FFNN menggunakan input dari lag PACF yang signifikan yaitu lag ke-1. Tahap awal pemodelan FFNN adalah normalisasi data dengan interval $[0,1]$. Kemudian, membentuk arsitektur jaringan dengan jumlah hidden layer sebanyak 1 dan menguji coba (trial and error) 2-10 neuron pada hidden layer untuk mendapatkan error model terkecil. Arsitektur yang terbentuk dapat diketahui pada Tabel 4 berikut. 
Tabel 4. Arsitektur jaringan FFNN Supiturang.

\begin{tabular}{ccccc}
\hline No. & Hidden Layer & Arsitektur Jaringan & RMSE training & RMSE testing \\
\hline 1 & 2 & FFNN (1-2-1) & 5,6241 & 3,4478 \\
2 & 3 & FFNN (1-3-1) & 5,6139 & 3,4375 \\
3 & 4 & FFNN (1-4-1) & 5,6192 & 3,4411 \\
4 & 5 & FFNN (1-5-1) & 5,6225 & 3,4448 \\
5 & 6 & FFNN (1-6-1) & 5,6185 & 3,4406 \\
6 & 7 & FFNN (1-7-1) & 5,6154 & 3,4377 \\
7 & 8 & FFNN (1-8-1) & 5,6281 & 3,4509 \\
8 & 9 & FFNN (1-9-1) & 5,6216 & 3,4447 \\
9 & 10 & FFNN (1-10-1) & 5,6246 & 3,4476 \\
\hline
\end{tabular}

Berdasarkan Tabel 4, model FFNN (1-3-1) memiliki RMSE data training terkecil sebesar 5,6139 dan RMSE data testing sebesar 3,4375. Pembentukan arsitektur FFNN ditentukan oleh bobot. Semakin besar bobot, semakin penting hubungan diantara neuron, hal tersebut dapat diketahui pada Tabel 5.

Tabel 5. Bobot akhir hidden layer ke output Supiturang.

\begin{tabular}{cc}
\hline $\mathrm{W}[\mathrm{i}]$, & $\mathrm{W}[, \mathrm{j}]$ \\
\cline { 2 - 2 } & 1 \\
\hline 0 & 0,4089 \\
1 & 0,9884 \\
3 & $-0,3619$ \\
\hline
\end{tabular}

Berdasarkan Tabel 3.5, dapat diketahui bahwa output model FFNN (1-3-1) secara matematis:

$\hat{Z}_{t}=b^{0}+w_{1}{ }^{0} f_{1}{ }^{h}+w_{2}{ }^{0} f_{2}{ }^{h}+w_{3}{ }^{0} f_{3}{ }^{h}$

$\hat{Z}_{t}=0,4089+0,9884 f_{1}{ }^{h}-0,3619 f_{2}{ }^{h}-0,7172 f_{3}{ }^{h}$

Data curah hujan kedua yang digunakan adalah data curah hujan di lokasi Manggisari. Gambaran awal mengenai curah hujan Manggisari dapat diketahui melalui plot curah hujan pada Gambar 2.

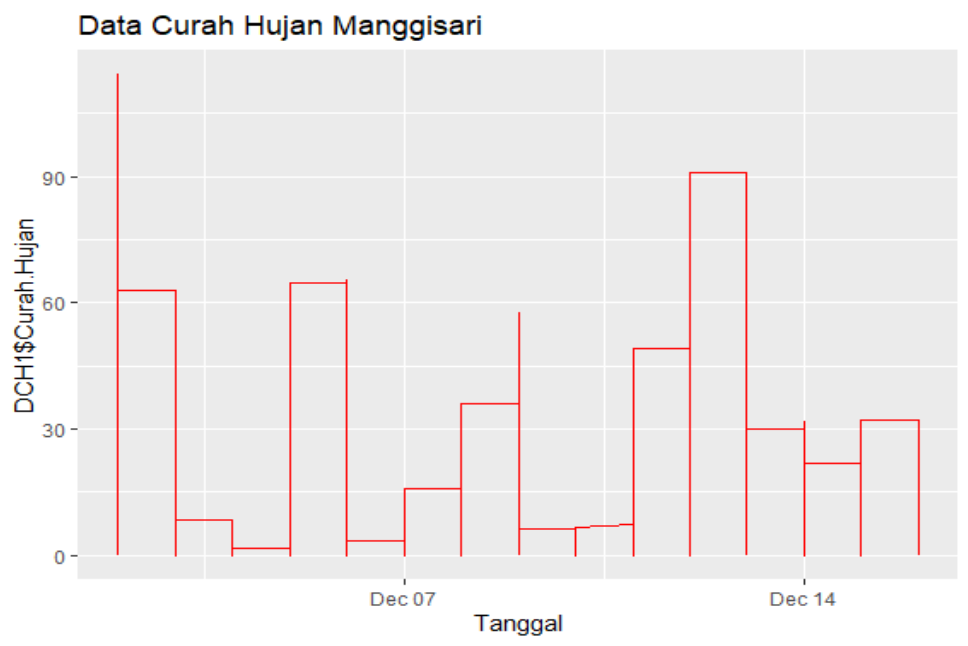

Gambar 2. Curah hujan daerah Manggisari.

Pada Gambar 2, diketahui awal bulan Desember terdapat curah hujan yang tinggi, sedangkan diakhir bulan Desember terjadi penurunan curah hujan. Sebagian besar curah hujan yang terjadi di Manggisari sebesar 19,94 mm dengan curah hujan maksimal sebesar 114,28 mm.

Sebelum melakukan pemodelan pada data curah hujan menggunakan pendekatan ARIMA, Hybrid ARIMA-NN dan FFNN, dilakukan pengujian linieritas terhadap data yang akan digunakan. Berdasarkan pengujian linieritas yang dilakukan, diketahui bahwa $p$-value $\left(2,2 \times 10^{-16}\right)<\alpha(0,05)$, maka dapat diputuskan menolak $\mathrm{H}_{0}$. Pada pengujian linieritas ini, dapat disimpulkan bahwa data curah hujan memiliki pola nonlinier. 
Penerapan metode neural network yang digunakan diharapkan dapat mengatasi data curah hujan di daerah Manggisari.

Pemodelan ARIMA Manggisari dilakukan untuk mendapatkan sisaan model ARIMA sebagai data input pada pemodelan Hybrid ARIMA-NN. Tahap awal ARIMA adalah pengecekan stasioneritas terhadap ragam dan rata-rata. Data Manggisari tidak stasioner terhadap ragam karena memiliki $\lambda$ sebesar 0,09 yang belum mendekati 1, sehingga diperlukan transformasi Box-Cox agar stasioner. Stasioneritas terhadap rata-rata diketahui melalui pengujian Augmented Dickey Fuller (ADF) dengan $p$-value $(0,01)<\alpha(0,05)$, sehingga data stasioneritas terhadap rata-rata. Tahap selanjutnya adalah pendugaan dan pengujian signifikansi parameter model yang dapat diketahui melalui Tabel 6 .

Tabel 6. Pendugaan parameter dan uji signifikansi model Manggisari.

\begin{tabular}{cccccc}
\hline \multirow{2}{*}{ Model } & Penduga & \multirow{2}{*}{ t hitung } & \multicolumn{2}{c}{ t tabel } & \multirow{2}{*}{ Keterangan } \\
\cline { 4 - 5 } & Parameter & & $t_{(0.05,2742}$ & $t_{(0.1,2742-p)}$ & \\
\hline \multirow{2}{*}{ ARIMA $(1,1,1)$} & $\phi_{1}=0,5845$ & 2.0246 & 1.9608 & 1.6454 & Signifikan \\
ARIMA $(1,1,0)$ & $\theta_{1}=-0,5591$ & 1.8998 & 1.9608 & 1.6454 & Signifikan \\
ARIMA $(0,1,1)$ & $\phi_{1}=0,0228$ & 1.1937 & 1.9608 & 1.6454 & Tidak Signifikan \\
\hline
\end{tabular}

Pada Tabel 6, diketahui bahwa hanya model ARIMA $(1,1,1)$ yang memiliki parameter signifikan, dengan koefisien penduga $\phi_{1}=0,5845$ dan $\theta_{1}=-0,5591$. Pengujian asumsi white noise dan normalitas sisaan ARIMA $(1,1,1)$, diketahui bahwa asumsi white noise terpenuhi karena $p$-value $(0,6367)>\alpha(0,05)$. Namun, pada asumsi normalitas tidak terpenuhi karena $p$-value $\left(2,2 \times 10^{-16}\right)<\alpha(0,05)$, hal ini terjadi dimungkinkan terdapat pencilan pada data Manggisari. Pemilihan model terbaik ARIMA yaitu ARIMA $(1,1,1)$ dengan persamaan sebagai berikut.

$$
\begin{aligned}
& Z_{t}=(1+\phi) Z_{t-1}+\phi Z_{t-2}+a_{t}-\theta_{1} a_{t-1} \\
& Z_{t}=1,5845 Z_{t-1}+0,5845 Z_{t-2}+a_{t}+0,5591 a_{t-1}
\end{aligned}
$$

Pemodelan Hybrid ARIMA-NN Manggisari menggunakan input sisaan ARIMA model terbaik. Tahap awal pemodelan Hybrid ARIMA-NN adalah normalisasi data dengan interval $[0,1]$. Kemudian, membentuk arsitektur jaringan dengan jumlah hidden layer sebanyak 1 dan menguji coba (trial and error) 2-10 neuron pada hidden layer untuk mendapatkan error model terkecil. Arsitektur yang terbentuk dapat diketahui pada Tabel 7 berikut.

Tabel 7. Arsitektur jaringan hybrid ARIMA-NN Manggisari.

\begin{tabular}{ccccc}
\hline No. & Hidden Layer & Arsitektur Jaringan & RMSE training & RMSE testing \\
\hline 1 & 2 & (ARIMA (1,1,1) FFNN (4-2-1)) & 5,6593 & 3,1029 \\
2 & 3 & (ARIMA (1,1,1) FFNN (4-3-1)) & 5,6831 & 3,1009 \\
3 & 4 & (ARIMA (1,1,1) FFNN (4-4-1)) & 5,6574 & 3,1021 \\
4 & 5 & (ARIMA (1,1,1) FFNN (4-5-1)) & 5,6522 & 3,1026 \\
5 & 6 & (ARIMA (1,1,1) FFNN (4-6-1)) & 5,6693 & 3,1017 \\
6 & 7 & (ARIMA (1,1,1) FFNN (4-7-1)) & 5,6653 & 3,1013 \\
7 & 8 & (ARIMA (1,1,1) FFNN (4-8-1)) & 5,6577 & 3,1002 \\
8 & 9 & (ARIMA (1,1,1) FFNN (4-9-1)) & 5,6439 & 3,1056 \\
9 & 10 & (ARIMA (1,1,1) FFNN (4-10-1)) & 5,6475 & 3,0991 \\
\hline
\end{tabular}

Berdasarkan Tabel 7, model ARIMA (1,1,1) FFNN (4-9-1) memiliki nilai RMSE data training terkecil sebesar 5,6439 dan RMSE data testing sebesar 3,1056. Pembentukan arsitektur Hybrid ARIMA-NN ditentukan oleh bobot. Semakin besar bobot, semakin penting hubungan diantara neuron, hal tersebut dapat diketahui pada Tabel 8. 
Tabel 8. Bobot akhir hidden layer ke output Manggisari.

\begin{tabular}{cc}
\hline $\mathrm{W}[\mathrm{i}]$, & $\mathrm{W}[\mathrm{j}]$ \\
\cline { 2 - 2 } 0 & $-0,1992$ \\
1 & $-0,2853$ \\
2 & $-0,4299$ \\
3 & 0,2205 \\
4 & 0,2359 \\
5 & $-1,0327$ \\
6 & 0,1914 \\
7 & $-0,0485$ \\
8 & $-0,2416$ \\
9 & 0,6070 \\
\hline
\end{tabular}

Berdasarkan Tabel 8, dapat diketahui bahwa output model Hybrid ARIMA $(1,1,1)$ FFNN (4-9-1) secara matematis:

$\widehat{N}_{t}=-0,1992-0,2853 f_{1}{ }^{h}-0,4299 f_{2}{ }^{h}+0,2205 f_{3}{ }^{h}+0,2359 f_{4}{ }^{h}-1,0327 f_{5}{ }^{h}+0,1914 f_{6}{ }^{h}-0,0485 f_{7}{ }^{h}-$ $0,2416 f_{8}{ }^{h}+0,6070 f_{9}{ }^{h}$

Model Hybrid ARIMA-NN terbaik adalah Hybrid ARIMA(1,1,1) FFNN (4-9-1) dengan persamaan sebagai berikut.

$\hat{Z}_{t}=\hat{L}_{t}+\widehat{N}_{t}$

$\hat{Z}_{t}=1,5845 Z_{t-1}+0,5845 Z_{t-2}+a_{t}+0,5591 a_{t-1}-0,1992-0,2853 f_{1}{ }^{h}-0,4299 f_{2}{ }^{h}+0,2205 f_{3}{ }^{h}+0,2359 f_{4}{ }^{h}-$ $1,0327 f_{5}{ }^{h}+0,1914 f_{6}{ }^{h}-0,0485 f_{7}{ }^{h}-0,2416 f_{8}{ }^{h}+0,6070 f_{9}{ }^{h}$

Pemodelan curah hujan FFNN menggunakan input lag PACF yang signifikan yaitu lag ke-1, Tahap awal pemodelan FFNN adalah normalisasi data dengan interval [0,1]. Kemudian, membentuk arsitektur jaringan dengan jumlah hidden layer sebanyak 1 dan menguji coba (trial and error) 2-10 neuron pada hidden layer untuk mendapatkan error model terkecil. Arsitektur yang terbentuk dapat diketahui pada Tabel 9 berikut.

Tabel 9. Arsitektur jaringan FFNN Manggisari.

\begin{tabular}{ccccc}
\hline No. & Hidden Layer & Arsitektur Jaringan & RMSE training & RMSE testing \\
\hline 1 & 2 & FFNN (1-2-1) & 3,1295 & 5,5464 \\
2 & 3 & FFNN (1-3-1) & 3,4733 & 5,3470 \\
3 & 4 & FFNN (1-4-1) & 3,5094 & 4,7497 \\
4 & 5 & FFNN (1-5-1) & 3,1509 & 5,5260 \\
5 & 6 & FFNN (1-6-1) & 3,1412 & 5,0899 \\
6 & 7 & FFNN (1-7-1) & 3,1315 & 5,0899 \\
7 & 8 & FFNN (1-8-1) & 3,1389 & 5,0356 \\
8 & 9 & FFNN (1-9-1) & 3,1389 & 4,6209 \\
9 & 10 & FFNN (1-10-1) & 3,1311 & 5,3042 \\
\hline
\end{tabular}

Berdasarkan Tabel 9, model FFNN (1-2-1) memiliki nilai RMSE data training terkecil sebesar 3,1295 dan RMSE data testing sebesar 5,5464. Pembentukan arsitektur FFNN ditentukan oleh bobot. Semakin besar bobot, semakin penting hubungan diantara neuron, hal tersebut dapat diketahui pada Tabel 10.

Tabel 10. Bobot akhir hidden layer ke output Manggisari.

\begin{tabular}{cc}
\hline $\mathrm{W}[\mathrm{i}]$, & $\mathrm{W}[, \mathrm{j}]$ \\
\cline { 2 - 2 } & 1 \\
\hline 0 & 1,0559 \\
2 & $-6,2379$ \\
2 & $-10,8860$ \\
\hline
\end{tabular}

Berdasarkan Tabel 10, dapat diketahui bahwa output model FFNN (1-2-1) secara matematis dapat ditulis sebagai berikut.

$\hat{Z}_{t}=b^{0}+w_{1}{ }^{0} f_{1}{ }^{h}+w_{2}{ }^{0} f_{2}{ }^{h}$

$\hat{Z}_{t}=1,0559-6,2379 f_{1}{ }^{h}-10,8860 f_{2}{ }^{h}$ 
Hasil validasi data Supiturang dan data Manggisari dapat diketahui pada Tabel 11.

Tabel 11. Hasil Validasi Data Supiturang dan Data Manggisari.

\begin{tabular}{|c|c|c|c|c|c|}
\hline \multirow[b]{2}{*}{ Metode } & \multicolumn{2}{|c|}{ Data Supiturang } & \multirow[b]{2}{*}{ Metode } & \multicolumn{2}{|c|}{ Data Manggisari } \\
\hline & $\begin{array}{c}\text { RMSE } \\
\text { Training } \\
\end{array}$ & $\begin{array}{l}\text { RMSE } \\
\text { Testing }\end{array}$ & & $\begin{array}{c}\text { RMSE } \\
\text { Training } \\
\end{array}$ & $\begin{array}{l}\text { RMSE } \\
\text { Testing }\end{array}$ \\
\hline ARIMA $(1,1,1)$ & 5,6056 & 3,4326 & $\begin{array}{c}\text { Hybrid (ARIMA } \\
(1,1,1) \text { FFNN }(4-9-1)\end{array}$ & 5,6439 & 3,1056 \\
\hline $\begin{array}{l}\text { Hybrid (ARIMA }(1,1,1) \\
\text { FFNN }(4-8-1)\end{array}$ & 10,2815 & 3,4334 & FFNN (1-2-1) & 3,1295 & 5,5464 \\
\hline FFNN (1-3-1) & 5,6139 & 3,4375 & & & \\
\hline
\end{tabular}

Berdasarkan Tabel 11, data Supiturang yang memiliki pola data linier didapatkan model terbaik yaitu model ARIMA $(1,1,1)$ dengan RMSE data testing terkecil dibandingkan model lain. Sedangkan pada data Manggisari yang memiliki pola data nonlinier didapatkan model terbaik dengan RMSE data testing terkecil pada model Hybrid (ARIMA $(1,1,1)$ FFNN (4-9-1)).

\section{KESIMPULAN}

Pemodelan curah hujan Supiturang diperoleh model ARIMA $(1,1,1)$ dengan RMSE testing 3,4326, metode Hybrid ARIMA-NN yaitu model (ARIMA $(1,1,1)$ FFNN (4-8-1)) dengan RMSE testing 3,4334, dan Pemodelan FFNN yaitu model FFNN (1-3-1) dengan RMSE testing 3,4375. Pemodelan curah hujan Manggisari diperoleh pada metode Hybrid ARIMA-NN yaitu model (ARIMA $(1,1,1)$ FFNN (4-9-1)) dengan RMSE testing 3,1056 dan pemodelan FFNN yaitu model FFNN (1-2-1) dengan RMSE testing 5,5464.

Model ARIMA $(1,1,1)$ merupakan model yang memiliki akurasi terbaik dalam meramalkan data yang berpola linier yaitu data curah hujan di Supiturang. Pada data yang memiliki pola nonlinier, metode Hybrid ARIMA (1,1,1) FFNN (4-9-1) merupakan model yang memiliki akurasi terbaik dalam meramalkan curah hujan di Manggisari.

\section{UCAPAN TERIMA KASIH}

Segala puji syukur kepada Allah SWT atas limpahan rahmat dan karunia-Nya, sehingga penulis mampu menyelesaikan jurnal yang disusun. Ucapan terima kasih atas kegiatan Hibah doktor-lektor FMIPA Universitas Brawijaya yang telah memberikan pendanaan untuk kegiatan penelitian ini.

\section{DAFTAR PUSTAKA}

Box, G. E. P., \& Jenkins, G. M. (1976). Time Series Analysis; Forecasting and Control. Holden-Day, Inc.

Iriany, A., Mahmudi, W. F., Nugroho, W. H., \& Sulistyono, A. D. (2019). Rainfall Forecasting Using GstarSur-Nn Approach in West Java Province. International Conference on Science, Engineering, Bulit Environment, and Social Science, 8, 161-165.

Iriany, A., Rosyida, D., Sulistyono, A. D., \& Ruchjana, B. N. (2020). Precipitation Forecasting Using Neural Network Model Approach. IOP Conference Series: Earth and Environmental Science, 458(1).

Patro, S. G. K., \& Sahu, K. K. (2015). Normalization : A Preprocessing Stage. 2(3), 2393-2395.

Rusdi. (2011). Uji Akar-Akar Unit dalam Model Runtun Waktu Autoregresif. Statistika, 11(2), 67-78.

Saputro, D. R. S. (2009). Memprediksi Curah Hujan (Data Spatio-Temporal) dengan Metode Bayesian Network. Proceeding of National Seminar on Research, Teaching, and Application of Mathematics and Science, 37-42.

Susanto, Y. (2016). Peramalan Curah Hujan dengan Pendekatan Model ARIMA, Feed Forward Neural Network dan Hybrid (ARIMA-NN) di Banyuwangi. Institut Teknologi Sepuluh November.

Wahyuni, I., Mahmudy, W. F., \& Iriany, A. (2017). Rainfall Prediction Using Hybrid Adaptive Neuro-Fuzzy Inference System (ANFIS) and Genetic Algorithm. Journal of Telecommunication, Electronic and Computer Engineering, 9(2-8), 51-56.

Wei, W. W. S. (2006). Time Series Analysis Univariate and Multivariate Methods (D. Lynch, S. Oliver, \& R. Hampton (eds.); 2nd ed.). Pearson Education.

Willmott, C. J., \& Matsuura, K. (2005). Advantages of the mean absolute error (MAE) over the root mean square error (RMSE) in assessing average model performance. Climate Research, 30(1), 79-82.

Zhang, G. P. (2003). Time Series Forecasting Using a Hybrid ARIMA and Neural Network Model. Neurocomputing, 50, 159-175. 